\title{
FAECAL FLORA OF SOUTH INDIAN INFANTS AND YOUNG CHILDREN IN HEALTH AND WITH ACUTE GASTROENTERITIS
}

\author{
M. J. Albert, P. Bhat, D. Rajan, P. P. Maiya, S. M. Pereira \\ AND S. J. BAKER \\ Wellcome Research Unit and Department of Child Health, \\ Christian Medical College Hospital, Vellore 632004, Tamil Nadu, India
}

INFORMATION regarding the faecal microbial flora in acute diarrhoeal states is very limited and the few detailed reports in the literature have been concerned mainly with adults (Moore, Cato and Holdeman 1969; Gorbach et al., 1970a; Gorbach et al., 1970b; Gorbach et al., 1971). Nothing is known about the faecal flora of infants and young children with diarrhoea of diverse aetiologies except for the results of one study dealing with the flora of infants with diarrhoea due to shigellosis (Mata, Mejicanos and Jimenez, 1972).

The present study was undertaken to define both qualitatively and quantitatively the normal faecal flora of southern Indian infants and young children and to determine the changes in acute gastroenteritis.

\section{MATERIALS AND METHODS}

Subjects. Forty-nine children aged 1 to 24 months with a diarrhoeal illness of 1 to 5 days' duration and sufficiently ill to require admission to hospital were studied. Twenty-nine apparently healthy children aged from 1 to 20 months served as controls. All the children were from the lower socio-economic strata. None had had any antimicrobial drug before the study began. The younger children were on breast-milk feeds often supplemented with cows' milk. The older children were also receiving cows' milk in addition to weaning foods.

Microbiological techniques. Fresh faecal specimens were collected in sterile containers and kept at $4^{\circ} \mathrm{C}$ until processed not more than $1 \mathrm{~h}$ later. Faeces $(0.5 \mathrm{~g}$, wet weight) were suspended in $4.5 \mathrm{ml}$ sterile normal saline and serial 10 -fold dilutions were made from $10^{1-10^{8}}$. These dilutions were cultured in $0 \cdot 1-\mathrm{ml}$ volumes on the surfaces of various media (Cruickshank, 1965). The details of media, methods of incubation and identification of the various groups of organisms were all as described by Bhat et al. (1972) except that Sarcina ventriculi was identified by the method of Crowther (1971). Enteric bacterial pathogens were detected by standard bacteriological techniques (Le Clair, Zen-Yoji and Sakai, 1970; Asakawa et al., 1973; Bhat, Shanthakumari and Rajan, 1974; Bhat and Rajan, 1975). From stool specimens not yielding recognised bacterial pathogens including the 10 serotypes of enteropathogenic Escherichia coli (EEC) 0111 : B4, O55 : B5, O26 : B6, O86: B7, O127: B8, O119 : B14, O124 : B17, O125:B15, O126: B16 and O128: B12, three colonies were held in deep nutrient agar to be examined later for other serotypes such as $E$. coli O20, O51 and O153 that are also associated with infantile diarrhoea (Ørskov et al., 1971). Final serological identification of the serotypes was made by Dr B. Rowe of the Salmonella and Shigella Reference Laboratory, Colindale, London.

Stools were also examined for the presence of rotavirus particles with a Philips EM-200 electron microscope and ammonium molybdate as a negative stain (Bishop et al., 1974).

Received 30 May 1977; revised version accepted 21 Sept. 1977. 


\section{RESULTS \\ Control subjects}

In all control subjects except two, the faecal flora was predominantly anaerobic with, on average, 126 anaerobes to each aerobe (figure). In the control group bifidobacteria were invariably found and gave rise to a mean count higher than that produced by any other organism (table I). The bulk of the aerobic flora consisted of enterobacteria and enterococci. Six EEC serotypes were cultured from the stools of five healthy infants (table II).

\section{TABLE I}

Rank order in terms of viable count of the anaerobic and aerobic bacterial groups in the faeces of 29 control subjects and 49 patients with diarrhoea*

\begin{tabular}{|c|c|c|c|c|c|}
\hline \multirow{2}{*}{ Bacterial group } & \multicolumn{2}{|c|}{$\begin{array}{c}\text { Data for } \\
\text { control group (29) }\end{array}$} & \multicolumn{2}{|c|}{$\begin{array}{l}\text { Data for } \\
\text { diarrhoeal group (49) }\end{array}$} & \multirow{2}{*}{$\begin{array}{c}\text { Statistical } \\
\text { significance } \\
\text { (P value) } \ddagger\end{array}$} \\
\hline & $\underset{\text { count } \uparrow}{\log _{10} \text { viable }}$ & $\begin{array}{l}\text { Rank } \\
\text { order }\end{array}$ & $\underset{\text { count } \dagger}{\log _{10} \text { viable }}$ & $\begin{array}{l}\text { Rank } \\
\text { order }\end{array}$ & \\
\hline \multicolumn{6}{|l|}{ Anaerobes } \\
\hline $\begin{array}{l}\text { Bifidobacteria } \\
\text { Anaerobic streptococci } \\
\text { Bacteroides } \\
\text { Veillonellae } \\
\text { Clostridia } \\
\text { Total anaerobes }\end{array}$ & $\begin{array}{c}10 \cdot 12 \pm 0.60(29) \\
9 \cdot 73 \pm 0.087(7) \\
8 \cdot 77 \pm 0.49(17) \\
8 \cdot 40 \pm 0.36(26) \\
5 \cdot 18 \pm 1 \cdot 19(8) \\
10 \cdot 31 \pm 0.55(29)\end{array}$ & $\begin{array}{r}1 \\
2 \\
3 \\
4 \\
8 \\
\ldots\end{array}$ & $\begin{array}{l}8 \cdot 60 \pm 0.33(40) \\
8.39 \pm 0.99(19) \\
7 \cdot 54 \pm 1 \cdot 53(25) \\
7.03 \pm 1.20(43) \\
4 \cdot 84 \pm 0.28(10) \\
8 \cdot 57 \pm 1.48(49)\end{array}$ & $\begin{array}{r}2 \\
3 \\
4 \\
7 \\
8 \\
\cdots\end{array}$ & $\begin{array}{l}<0.0001 \\
\text { NS } \\
<0.02 \\
<0.001 \\
\text { NS } \\
<0.0001\end{array}$ \\
\hline $\begin{array}{l}\text { Aerobes } \\
\text { Enterobacteria } \\
\text { Enterococci } \\
\text { Lactobacilli } \\
\text { Yeasts } \\
\text { Staphylococci } \\
\text { Total aerobes }\end{array}$ & $\begin{array}{l}8.28 \pm 0.86(28) \\
7.75 \pm 1.03(28) \\
6.94 \pm 1.16(23) \\
4.02 \pm 1.52(17) \\
3.45 \pm 0.61(9) \\
8.70 \pm 0.76(20)\end{array}$ & $\begin{array}{r}5 \\
6 \\
7 \\
9 \\
10 \\
\ldots\end{array}$ & $\begin{array}{l}8.89 \pm 0.92(48) \\
7.44 \pm 1 \cdot 36(42) \\
7.05 \pm 1.27(30) \\
4 \cdot 24 \pm 1.55(36) \\
4.44 \pm 1.07(7) \\
9 \cdot 12 \pm 0.83(49)\end{array}$ & $\begin{array}{r}1 \\
5 \\
6 \\
10 \\
9 \\
\ldots\end{array}$ & $\begin{array}{r}<0.01 \\
N S \\
N S \\
N S \\
<0.05 \\
<0.05\end{array}$ \\
\hline
\end{tabular}

* Arithmetic mean for each bacterial group was calculated, unless that group could not be demonstrated. Values are expressed as $\log _{10}$ bacterial count per $\mathrm{g}$ of wet faeces \pm 1 SD.

$\dagger$ Figures in parenthesis indicate numbers of children in whom the bacterial groups were present. $\ddagger \mathrm{NS}=$ Not significant.

\section{TABLE II}

Rank order of viable count of pathogens amongst the various bacterial groups present in the faeces of five of 29 control children

\begin{tabular}{c|ccc}
\hline Subject & Pathogen & $\begin{array}{c}\text { Log } 10 \text { viable } \\
\text { count per g }\end{array}$ & $\begin{array}{c}\text { Rank } \\
\text { order }\end{array}$ \\
\hline & EEC O111 : B4 & 8.00 & 2 \\
2 & EEC O111 : B4 & 8.40 & 4 \\
3 & EEC O111 : B4 & $8 \cdot 30$ & 4 \\
4 & EEC O128: B12 & 6.00 & 6 \\
5 & EEC O26: B6 & 6.85 & 5 \\
EEC O119: B14 & 6.70 & 6 \\
\hline
\end{tabular}

$\mathrm{EEC}=$ Enteropathogenic Escherichia coli. 


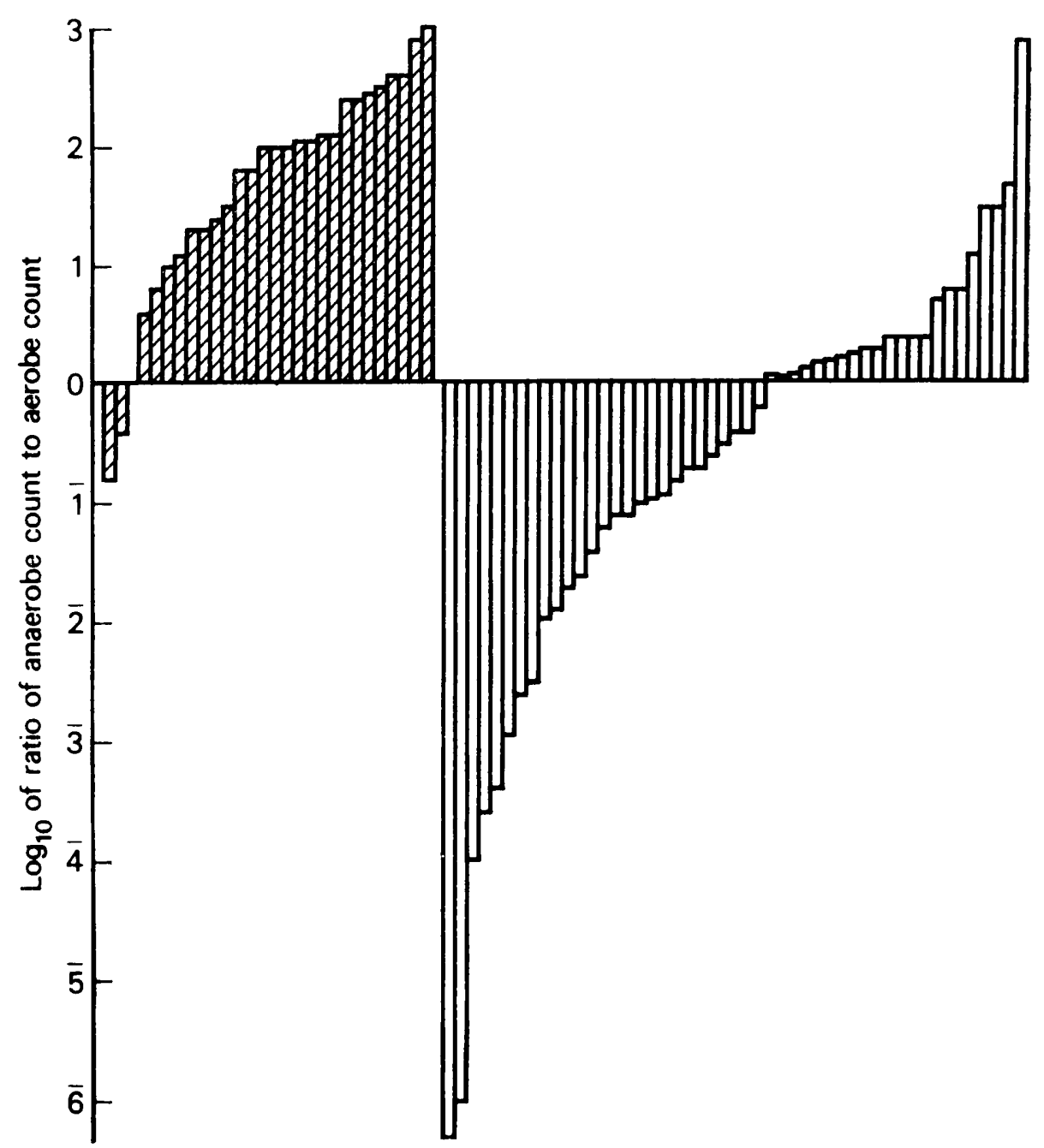

FIGURE-The ratio of anaerobic organisms to aerobic organisms in the faeces of control children

$(\mathbb{Z})$ and patients with diarrhoea ( $\square$ ).

\section{Children with diarrhoea}

There was a striking change in the proportion of anaerobes to aerobes in the children with diarrhoea, and in 27 the aerobes predominated (figure). The ratio of the mean of total anaerobes to mean of total aerobes was significantly lower than in the control group $(\mathbf{P}<0 \cdot 001)$. Enterobacteria were found in all but one of the diarrhoeal samples and in the group of children as a whole they predominated over any other type of organism present (table I). Bifidobacteria, bacteroides organisms and veillonellae were present in significantly greater numbers in controls than in patients. Conversely, enterobacteria and staphylococci were found in significantly greater numbers in patients than in controls (table I). 
TABLE III

Rank order of viable count of pathogens amongst the various bacterial groups present in the faeces of 28 of 49 patients with diarrhoea

\begin{tabular}{|c|c|c|c|}
\hline Patient & Pathogen & $\begin{array}{l}\log _{10} \text { viable } \\
\text { count per } \mathbf{g}\end{array}$ & Rank order \\
\hline $\begin{array}{r}1 \\
2 \\
3 \\
4 \\
5 \\
6 \\
7 \\
8 \\
9 \\
10 \\
11 \\
12 \\
13 \\
14 \\
15 \\
16 \\
17 \\
18 \\
19 \\
20 \\
21 \\
22 \\
23 \\
24 \\
25\end{array}$ & 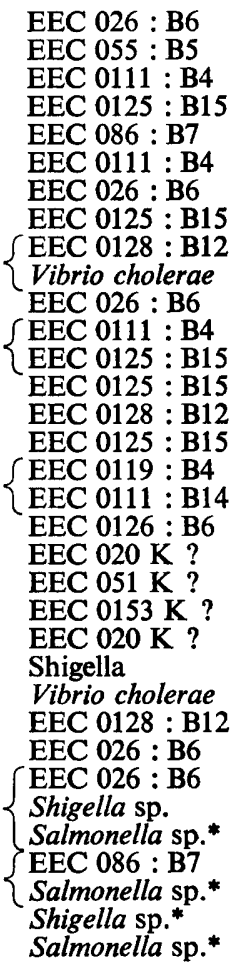 & $\begin{array}{r}9 \cdot 12 \\
9 \cdot 04 \\
10 \cdot 00 \\
10.04 \\
7 \cdot 40 \\
8 \cdot 61 \\
6.04 \\
7.97 \\
7 \cdot 82 \\
7 \cdot 91 \\
8 \cdot 74 \\
6 \cdot 96 \\
6 \cdot 96 \\
6 \cdot 60 \\
9 \cdot 40 \\
10 \cdot 11 \\
8 \cdot 54 \\
8 \cdot 54 \\
8 \cdot 87 \\
7 \cdot 20 \\
8 \cdot 45 \\
9 \cdot 76 \\
8 \cdot 69 \\
7 \cdot 00 \\
6 \cdot 30 \\
9 \cdot 32 \\
7 \cdot 43 \\
8 \cdot 18 \\
7 \cdot 30 \\
\ldots .6 \\
8 \cdot 63 \\
\ldots \\
\ldots . \\
\ldots\end{array}$ & $\begin{array}{l}1 \\
1 \\
1 \\
1 \\
1 \\
2 \\
4 \\
3 \\
6 \\
5 \\
1 \\
1 \\
1 \\
2 \\
2 \\
1 \\
1 \\
1 \\
1 \\
3 \\
2 \\
1 \\
3 \\
2 \\
2 \\
1 \\
3 \\
2 \\
5 \\
\dddot{1} \\
\ldots \\
\cdots \\
\ldots\end{array}$ \\
\hline
\end{tabular}

Rotavirus particles were demonstrated in the stools of 13 children with diarrhoea. A total of 34 bacterial pathogens were isolated from 28 of the children with diarrhoea. Of these, four (three Salmonella spp. and one Shigella spp.) could not be counted as they were obtained by plating undiluted faeces on special media and were presumably present in only small numbers. The remaining 30 were counted and their numbers compared with those of other organisms (table III).

Sarcina ventriculi was not found in the control subjects but was isolated from one patient in low numbers $\left(10^{2}\right.$ per $\mathrm{g}$ of faeces).

\section{Discussion}

In the present study, the most common organisms in faeces of normal infants were bifidobacteria, viellonellae, enterobacteria and enterococci with 
the anaerobes outnumbering the aerobes. This is in broad agreement with studies from Guatemala (Mata, Carrillo and Villatoro, 1969; Mata and Urrutia, 1971) and England (Ellis-Pegler, Crabtree and Lambert, 1975) that are summarised in table IV. The reasons for the differences between the counts of the different groups of organisms are probably complex and include differences in age, diet, environmental hygiene and methodology.

In the children with diarrhoea in the present study, the faecal anaerobes were reduced in number so that the ratio of anaerobes to aerobes was reversed. No significant difference in terms of faecal flora could be found between children with bacterial diarrhoea and those with diarrhoea of presumed viral origin. Children with diarrhoea exhibited similar changes in faecal flora regardless of the presence or absence of bacterial or viral pathogens.

The only previous study of faecal flora in children with diarrhoea is that of Mata et al. (1972) of patients with shigellosis. They did not find significant changes in the faecal flora during mild or moderate diarrhoeal disease, but in severe diarrhoea with dehydration they too observed a prodominance of aerobes, attributable both to an increase in the numbers of aerobes and a reduction in the number of anaerobes. We did not find a relationship between the severity of the diarrhoea, the severity of the dehydration or the requirements for parenteral fluid therapy, and the degree of alteration in the ratio of anaerobes to aerobes. It is possible that all our patients had a diarrhoea more severe than that in the " mild or moderate" disease described by Mata et al. (1972).

Moore et al. (1969) and Gorbach et al. (1971) described an increase in faecal aerobes with a reduction in anaerobes in adults with acute gastroenteritis due to a variety of bacterial pathogens, and in adult volunteers with diarrhoeal states produced by purgation (Gorbach et al., 1970b). The changes

TABLE IV

Reported prevalence of various bacterial groups in the faeces of normal infants

\begin{tabular}{|c|c|c|c|c|}
\hline \multirow[b]{2}{*}{$\begin{array}{l}\text { Bacterial } \\
\text { group }\end{array}$} & \multicolumn{4}{|c|}{$\begin{array}{l}\text { Percentage of infants and young children with faeces containing the stated } \\
\text { bacterial groups, as reported in }\end{array}$} \\
\hline & $\begin{array}{c}\text { Guatemala by Mata } \\
\text { et al. }(1969) \text { who } \\
\text { studied } 19 \text { subjects } \\
2-4 \text { months }\end{array}$ & $\begin{array}{c}\text { Guatemala by Mata } \\
\text { and Urrutia (1971) } \\
\text { who studied 12 } \\
\text { subjects aged } \\
0-9 \text { months }\end{array}$ & $\begin{array}{l}\text { the UK by Ellis- } \\
\text { Pegler et al. }(1975) \\
\text { who studied } 33 \text { subjects } \\
\text { aged } 0-12 \text { months }\end{array}$ & $\begin{array}{l}\text { the present } \\
\text { study of } 29 \\
\text { subjects aged } \\
1-20 \text { months }\end{array}$ \\
\hline $\begin{array}{l}\text { Bifidobacteria } \\
\text { Bacteroides } \\
\text { Veillonellae } \\
\text { Clostridia } \\
\text { Anaerobic }\end{array}$ & $\begin{array}{r}100 \cdot 0 \\
15 \cdot 8 \\
84 \cdot 2 \\
10 \cdot 5\end{array}$ & $\begin{array}{r}98 \cdot 5 \\
28 \cdot 6 \\
59 \cdot 9 \\
6 \cdot 5\end{array}$ & $\begin{array}{l}87 \cdot 9 \\
85 \cdot 0 \\
91 \cdot 0 \\
94 \cdot 0\end{array}$ & $\begin{array}{r}100 \cdot 0 \\
58 \cdot 6 \\
89 \cdot 6 \\
27 \cdot 6\end{array}$ \\
\hline $\begin{array}{l}\text { streptococci } \\
\text { Enterobacteria } \\
\text { Enterococci } \\
\text { Lactobacilli } \\
\text { Stanhylococci }\end{array}$ & $\begin{array}{l}47 \cdot 3 \\
89 \cdot 5 \\
78 \cdot 9 \\
26 \cdot 3\end{array}$ & $\begin{array}{l}58 \cdot 0 \\
88 \cdot 9 \\
70 \cdot 2 \\
10 \cdot 3\end{array}$ & $\begin{array}{l}100 \cdot 0 \\
100 \cdot 0^{*} \\
24 \cdot 2\end{array}$ & $\begin{array}{l}24 \cdot 1 \\
96 \cdot 6 \\
96 \cdot 6 \\
79 \cdot 3\end{array}$ \\
\hline+ micrococci & $100 \cdot 0$ & $97 \cdot 3$ & $97 \cdot 0$ & $34 \cdot 5$ \\
\hline
\end{tabular}

* Reported as streptococci. 
in the faecal flora in diarrhoeal states are therefore presumably related to nonspecific alterations in the micro-environment of the colon and are not directly related to the causative agent. Normally, the oxygen-sensitive anaerobes find in the large intestine conditions of low oxidation-reduction potential and relative stasis that are conducive to growth. The rapid passage of intestinal contents that occurs in diarrhoea appears to produce a less favourable environment (Gorbach et al., 1971).

In 13 of the 28 children with diarrhoea, whose faeces contained indentifiable bacterial pathogens, the causative bacteria were at the time of sampling the predominant faecal organisms. Dale and Mata (1968) observed that in chronic recurrent shigellosis in malnourished children in central America there appeared to be a relationship between the relative number of shigellae in the stools and the severity of the diarrhoea. Presumably the proportion of pathogenic bacteria in the faecal flora varies with the stage of the disease. Gorbach et al. (1970a) found that in the acute phase of cholera, Vibrio cholerae was the predominant organism in the stool and that it decreased in numbers during convalescence.

In five of the control children, six EEC serotypes were found. It is well known that these organisms can be isolated from apparently healthy children but it was surprising to find that in one child such a serotype was present in large numbers $\left(10^{8}\right.$ per $\mathrm{g}$ of faeces) and was the second most numerous organism in the stool. It is possible that this particular serotype was not producing enterotoxin.

Sarcina ventriculi was found by Crowther (1971) in the stools of $71 \%$ of adults living on a predominantly vegetarian diet. We have been unable to find any report of its distribution in the faeces of infants and young children. This study showed that in such a population it was very uncommon, occurring in only one of 78 specimens, though a study of older children (2-7 years) from a similar background showed the organism to be present in $67 \%$ (Bhat, Shanthakumari and Rajan, to be published).

\section{SUMMARY}

The faecal flora of 29 healthy infants and young children was compared with that of 49 children of similar age and socio-ecomonic status with acute gastroenteritis. In the healthy children the most common organisms in the faeces were bifidobacteria, veillonellae, enterobacteria and enterococci with anaerobes outnumbering aerobes. Most members of the normal faecal flora were present in the diarrhoeal stools, but anaerobes were significantly reduced in number and enterobacteria were significantly increased, thereby altering the ratio of anaerobes to aerobes. The alterations in the flora were not related to the nature of the aetiological agent or to the severity of the diarrhoea. The changes appeared to be a direct result of the altered colonic environment produced by the diarrhoeal state. In 13 of the 28 patients from whom bacterial pathogens were isolated, the pathogens were the predominant faecal organisms.

The authors are grateful to Dr B. Rowe, Salmonella and Shigella Reference Laboratory, Colindale, London, for serotyping some of the Escherichia coli isolates. 


\section{REFERENCES}

Asakawa, Y., Akahane, S., Kagata, N., Noguchi, M., Sakazaki, R. and Tamura, K. 1973. Two community outbreaks of human infection with Yersinia enterocolitica. J. Hyg., Camb., 71, 715.

Bhat, P. AND RAJAN, D. 1975. Comparative evaluation of desoxycholate citrate medium and xylose lysine desoxycholate medium in the isolation of shigellae. Am. J. clin. Path., 64, 399.

Bhat, P., Shanthakumari, S. and Rajan, D. 1974. The characterization and significance of Plesiomonas shigelloides and Aeromonas hydrophilia isolated from an epidemic of diarrhoea. Indian J. med. Res., 62, 1051.

Bhat, P., Shanthakumari, S., Rajan, D., Mathan, V. I., Kapadia, C. R., Swarnabai, C. AND BAKER, S. J. 1972. Bacterial flora of the gastrointestinal tract in southern Indian control subjects and patients with tropical sprue. Gastroenterology, 62, 11.

Bishop, R. F., Davidson, G. P., Holmes, I. H. AND Ruck, B. J. 1974. Detection of a new virus by electron microscopy of faecal extracts from children with acute gastroenteritis. Lancet, 1, 149.

Crowther, J. S. 1971. Sarcina ventriculi in human faeces. J. med. Microbiol., 4, 343.

Cruickshank, R. 1965. Medical microbiology, 11th ed., Edinburgh, p. 870.

Dale, D. C. ANd Mata, L. J. 1968. Studies of diarrhoeal disease in Central America. XI. Intestinal bacterial flora in malnourished children with shigellosis. Am. J. trop. Med. Hyg., 17, 397.

Ellis-Pegler, R. B., Crabtree, C. and Lambert, H. P. 1975. The faecal flora of children in the United Kingdom. J. Hyg., Camb., 75, 135.

Gorbach, S. L., Banwell, J. G., Chatterjee, B. D., Jacobs, B. and Sack, R. B. 1971. Acute undifferentiated human diarrhoea in the tropics. I. Alterations in intestinal microflora. J. clin. Invest., 50, 881.

Gorbach, S. L., Banwell, J. G., Jacobs, B., Chatterjee, B. D., Mitra, R., Brigham, K. L. AND NeOGY, K. N. 1970a. Intestinal microflora in Asiatic cholera. I. "Rice-water" stool. J. infect. Dis., 121, 32.

Gorbach, S. L., Neale, G., Levitan, R. and Hepner, G. W. 1970b. Alterations in human intestinal microflora during experimental diarrhoea. Gut, 11, 1.

Le Clair, R. A., ZeN-YoJ, H. and SAKaI, S. 1970. Isolation and identification of Vibrio parahaemolyticus from clinical specimens. Publ. Hlth Lab., 28, 82.

Mata, L. J., Carrillo, C. AND Villatoro, E. 1969. Faecal microflora in healthy persons in a preindustrial region. Appl. Microbiol., 17, 596.

Mata, L. J., Mejicanos, M. L. ANd Jimenez, F. 1972. Studies on the indigenous gastrointestinal flora of Gautemalan children. Am. J. clin. Nutr., 25, 1380.

MATA, L. J. AND URRUTIA, J. J. 1971. Intestinal colonization of breast-fed children in a rural area of low socio-economic level. Ann. N.Y. Acad. Sci., 176, 93.

Moore, W. E. C., Cato, E. P. and Holdeman, L. V. 1969. Anaerobic bacteria of the gastrointestinal flora and their occurrence in clinical infections. J. infect. Dis., 119, 641.

ØrSKOV, F., ØRSKOV, I., JANN, B. AND JANN, K. 1971. Immuno-electrophoretic patterns of extracts from all $E$. coli $\mathrm{O}$ and $\mathrm{K}$ antigen test strains correlation with pathogenicity. Acta path. microbiol. scand., Section B, 79, 142. 